\title{
Nomad Iconography on Tombstones from Luristan, Iran
}

In Luristan in western Iran the nomad cemeteries are scattered apparently at random across the landscape. The history of these nomads is not very well known, and until a few years ago they were themselves largely illiterate. ${ }^{1}$ They have lived in areas which comprise some of the very isolated mountain valleys and plains in the central Zagros mountains, and until recently their rhythm of life was to a great extent determined by the changing seasons, a fact that is reflected in the changing settlement patterns (Edelberg 1966-67, 373-401). The nomads covered a large distance during the course of a year, and as the seasons changed so did their dwellings. The mobile camps of black tents or airy huts leave only slight traces

\footnotetext{
${ }^{1}$ The fieldwork upon which this study is based was carried out in 1974, when I was a member of a Danish archaeological expedition to Luristan. The expedition was sponsored by the Danish Carlsberg Foundation and the Archaeological Service of Iran. A grant from the Central Institute of Asian Studies, Copenhagen enabled me to return to Luristan in the autumn of 1977.

In the valley of Hulailan, approximately midway between Shahabad and Khorramabad, the cemetery of Pela Kabud was mapped and examined in detail. Pela Kabud is the largest cemetery in the area, comprising the remains of more than 600 graves, of which 379 still had the tombstones preserved. The oldest datable stone is from $1200 \mathrm{AH} / 1785$ $\mathrm{AD}$. The cemetery is still in use, although the types of tombstones described below are no longer produced. Fifteen other cemeteries were located in the Hulailan valley and studied in some detail.

In 1977 the survey was extended to cover larger regions of Pish-i Kuh and Pusht-i Kuh. It revealed numerous cemeteries with graves from the last two hundred years, and with gravestones, obelisks and stelae generally falling within the typological framework described below. - The distribution of cemeteries with pictorial gravestones and stelae seems to fall in the central and northern parts of Luristan in the plains of Kuh-i Dasht, Rumishgan, Bouleran, Tarhan and Hulailan, and in the small valleys along the Saimarreh river in the northern part of Pish-i Kuh towards Gamas Ab and Qara Su, south-west of Harsin.

An earlier version of this paper appeared under the title 'From Ritual Action to Symbolic Communication' (Mortensen 1991)
} 
on the surface of the ground, and after a short time it is difficult to detect even a large camp-site.

The cemeteries and the tombstones which I have studied cover a period from the late $18^{\text {th }}$ century to the middle of this century (Mortensen 1983: 26-47). Starting early in the 1920's Reza Shah and his army attempted to forcibly, 'civilize' - that is, to disarm and settle - the nomadic tribes of Luristan. By the mid1930's this policy had resulted in an economic, social and cultural breakdown of the old tribal structures of Luristan and in a partial cessation of nomadic migrations. The old cemeteries and tombstones of which I made a study in the 1970's, nearly all placed along old migratory routes, may therefore be an important source for the mapping of tribal migrations during the $19^{\text {th }}$ and early $20^{\text {th }}$ centuries. Moreover, they contain a rich amount of evidence for an understanding of certain aspects of the religious beliefs and ritual actions of the Lurs. (Fig. 1).

There are several kinds of tombstone in Luristan. A pictorial stele or an obelisk may sometimes be associated with the grave, and some of the obelisks can reach a height of several metres. Most common, however, are flat-lying gravestones with inscriptions in a lapidary style, which always state the name of the deceased, the name of his or her father, and the name of the tribe (tayefeh) to which he belonged. The month in which the death occurred is sometimes indicated, and always the year, according to the Islamic lunar calendar. An example is shown in Figure 2: the gravestone of a woman, of the Jalalvand tribe. A panel with gender-related pictorial symbols is nearly always found at the base of the gravestone. In this case, for example, there are a double-edged woman's comb, a kohl-pin, a prayer-stone, and a pair of scissors. The most common symbols on men's gravestones are: a washing set consisting of a basin and ewer, a string of prayer-beads, a prayer stone, and a semi-circular comb. Figure 3 shows these symbols on the gravestone of a man who died in Rajab in 1257 AH/August-September 1841.

In order to arrive at an interpretation of these images on gravestones, obelisks and stelae, the obvious procedure would be to ask the local people, the Lurs, among whom the tradition was once alive. It is rather surprising, however, that none of the local people who were interviewed could give any explanation of the background for, or the meaning of, the various signs and symbols on the tombstones. Their answers were nearly always in the negative - and with regret. That this would most often be followed up by much curious and fanciful speculation and suggestions does not disguise the fact that the signs have lost their original message-carrying value for the local people today. 
In these interviews in Luristan I used to worry about the problems of accurate communication on the elementary level of linguistic difficulties and inadequacies. In spite of a seemingly fine rapport, did the people really understand, what I was asking? This worry was partly overcome by Professor Gernot Windfuhr, of the University of Michigan, Ann Arbor, an expert on the dialects spoken in Luristan. He very kindly asked many of 'my' questions, and there is no doubt whatever that the questions and answers were perfectly understood in the literal sense. However, a doubt remains which is difficult to put into words and which may perhaps be best explained by the following example. In 1977 two Danish children, aged 6 and 9 , accompanied the expedition to Luristan. The only toy they had was a $20 \times 20 \times 5 \mathrm{~cm}$ box containing 4 or 5 layers of different jig-saw puzzles cut out in wood and with pictures on one side. The first layer was cut into 4 pieces, the second into 8 pieces and so on. The children were very familiar with geometric puzzle toys, and would often turn the pieces upside down to make it more 'difficult', i.e. more fun. The Lurs were quite fascinated by this game. Some of the men would always sit and watch, and they liked to try the game themselves. The interesting or curious thing is that they could hardly do it. Nobody ever got beyond the second layer with the pictures up, and even that took almost half an hour. Obviously this has nothing to do with 'intelligence'. Rather it may have something to do with the different way in which visual images are encoded or impressed upon our brains at a very early age - and this might explain the difficulties of cross-cultural image interpretation or code-breaking. Even if communication is perfect at the level of speech or language, the images or ideas evoked by the words may be so 'out of focus' that a mutual understanding of abstract ideas or notions is hardly possible. Nevertheless, I should like to briefly present two examples of my interpretation of images on Luristani tombstones. In both cases an attempt is made to understand the symbols through a reconstruction of the original religious and ritual context of the images.

The first example is an image which appears on a number of tombstones. It occurs e.g. on the tombstone of a man of the Jalalvand tribe who died in $1257 \mathrm{AH} / 1841 \mathrm{AD}$ (Fig. 4). Below the inscription is a frame with the usual male symbols: a string of prayer-beads, the prayer stone, a ewer, and to the left a semi-circular man's comb. In the middle of the stone, interspaced between the fourth and the fifth lines of the inscription, is a panel with an enigmatic geometric figure in the centre: a cross on a square background with a kind of step design on both sides, opening up into tiny channels leading out from, or into, the centre. 
The simplest interpretation of this motif, and none was forthcoming from the local people, is that it is a purely decorative element - an ornament designed to fill the space between two lines. There is, however, another possibility: the pattern looks very much like the central motifs in the great Persian Garden carpets of the $17^{\text {th }}$ and $18^{\text {th }}$ centuries. These represent, by means of geometrically constructed designs, a garden with channels leading out of, or into, the central motif, precisely like the middle panels on the tombstones. In the carpets the garden motif with its water channels and pools was very naturalistically portrayed, in the sense that an attempt was made to imitate or reproduce the plan of the classical Islamic garden (cf. eg. Rainer 1977: 174-191; Thacker 1979: figs. 13, 15 and 16; Macdougall and Ettinghausen 1976: pl II-IV, XXII-XXV, XXXI; Wilber 1962). In the carpets the channels and pools symbolize the water channels in a real garden, or, by extension, in the bagh-e bihisht - the Garden of Paradise. In Paradise imagery the setting is a garden or a series of gardens "... underneath which rivers flow ..." - a phrase occurring some thirty times in the Qur'an. Moreover, the pleasures of the bagh-e bihisht are so vividly described in the Qur'an that it has been an inexhaustible source of inspiration for miniature-painters, poets, saints and sufis alike, as well as for ordinary mortals. They all carry a mental image of Paradise! This notion of the all-pervading essence and presence of God can hardly be better expressed than in the following quotation from a poem by the medieval Islamic mystic Yunus Emre (quoted in Schimmel 1976: 13):

The rivers all in Paradise

flow with the word Allah, Allah, and ev'ry longing nightingale he sings and sings Allah, Allah!

The branches of the Tuba tree the tongue reciting the Koran, the roses there in Paradise, their fragrance is Allah, Allah!

The evident appeal of these delightful and evocative verses to the senses of sight, hearing and smell could easily be explained as a response to ecological conditions. For nomads living in hot and arid lands, the attraction of walled gardens with trickling water, and palmtrees and pomegranates giving both shade and fruit, is obvious. In addition, ever since the Arab conquest in the $7^{\text {th }}$ century these gardens have been the living image of the Islamic Paradise for the Persians. For a Muslim who has lived in accordance with the orthodox religious requirements, there should be no reason 


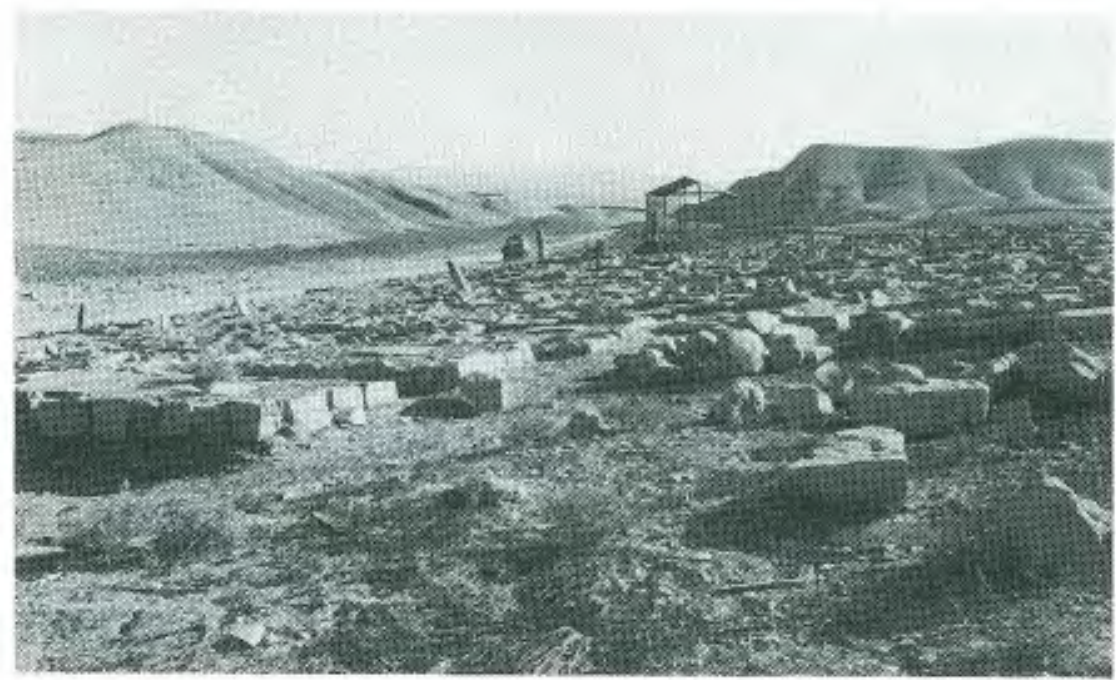

Fig. 1. View of the cemetery of Pela Kabud in the Hulailan valley, Luristan. (Photo: September 1977).

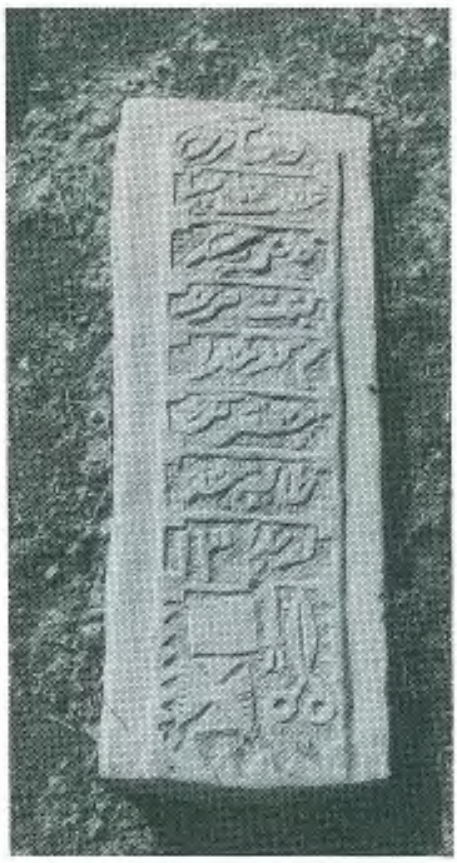

Fig. 2. Pela Kabud. Woman's tombstone. Date incomplete (13. AH) (Photo: September 1977).

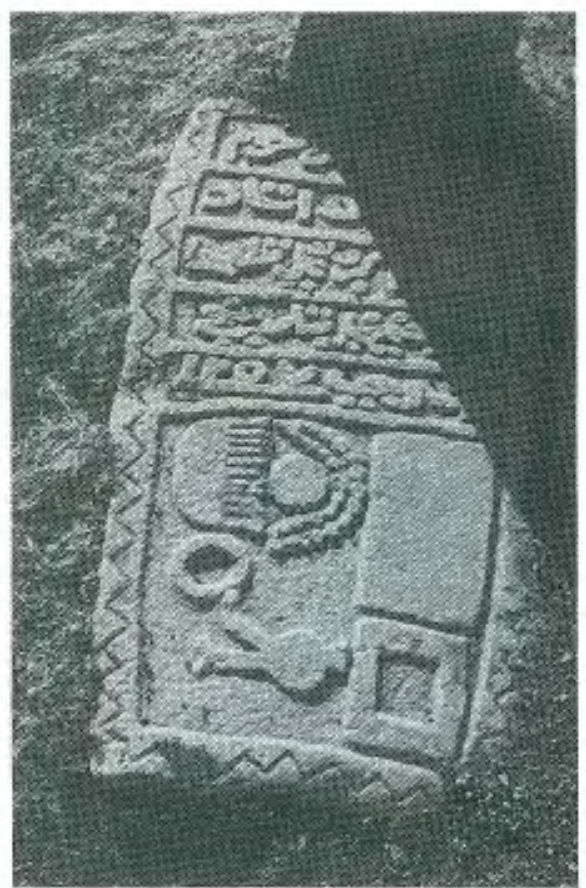

Fig. 3. Pela Kabud. Man's tombstone. Date: Rajab 1257 A.H. Aug./September 1841 A.D. (Photo: September 1977). 


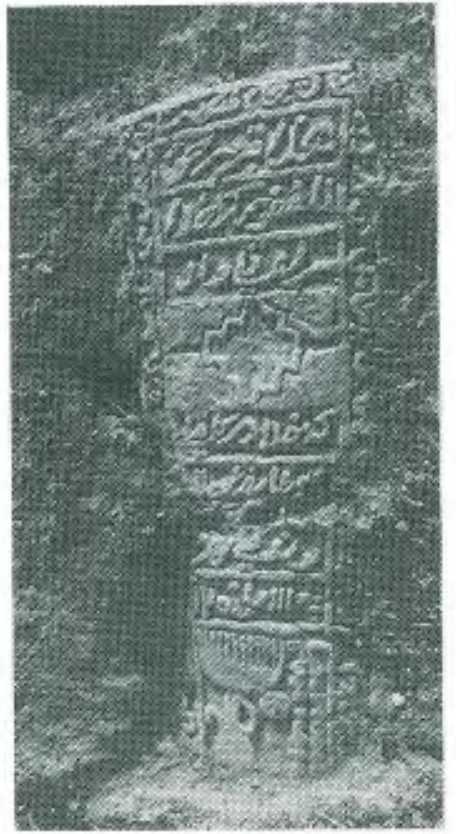

Fig. 4. Pela Kabud. Man's tombstone. Date: 1257 A.H. 1841/42 A.D. (Photo: September 1977).

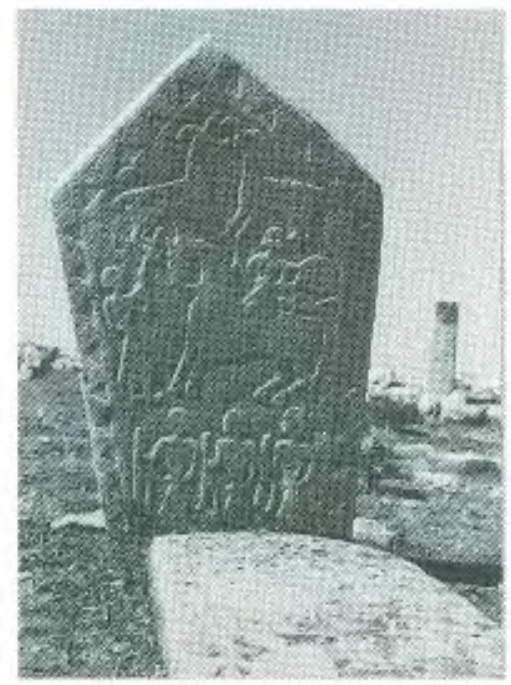

Fig. 5a. Pela Kabud. Man's stele. Date: Rajb 1299 A.H. - May/June 1882 A.D. (Photo: October 1975).

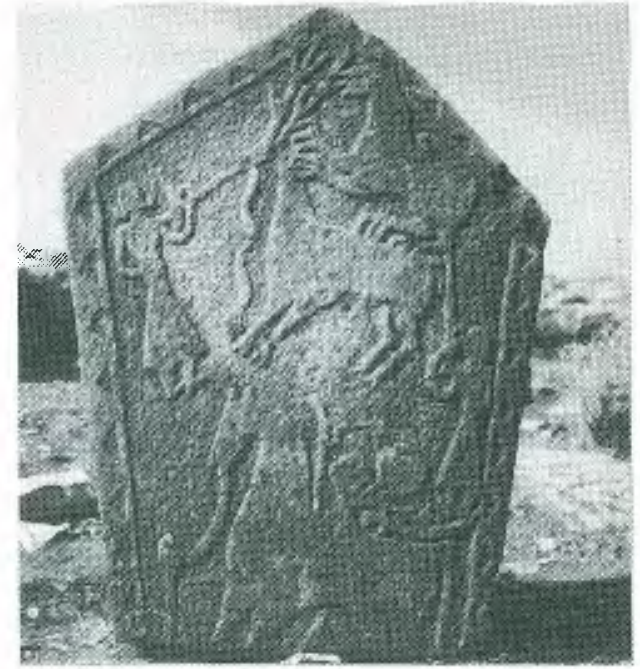

Fig. 6. Pela Kabud. Man's stele.

Date uncertain. (the stele was not found in situ) (Photo: October 1975).

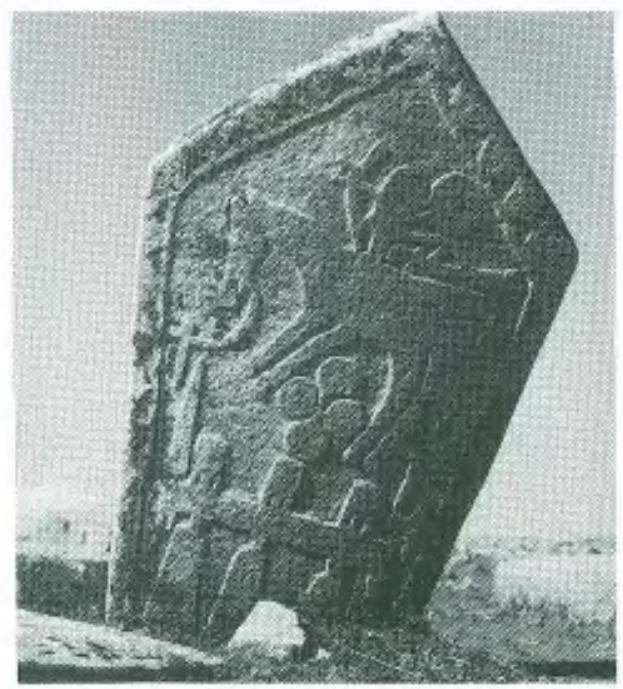

Fig. 5b. Pela Kabud. Man's stele. Date: Rabi-ol-Sani, 1274 A.H. November/December 1857 A.D. (Photo: October 1975). 
to fear death, for he may rest assured - or at least may hope - that on the Day of Judgment, after the resurrection, he will be allotted a place in Paradise, and will forever after enjoy the pleasures of the Garden of Eden so eloquently described in the Qur'an.

Against this background and in this religious context it is possible to suggest that the geometric motifs of the middle panels on the tombstones, like the central figures of the garden carpets, fulfil not only a decorative purpose, but also contain symbolic connotations, which would direct thought towards bagh-e bihisht, the Garden of Paradise.

The second example of an image from the range of symbolic representations on Luristani tombstones is a motif found on almost all of the stelae erected at the heads of graves. The stelae have pictures on both sides showing distinctly differing themes. One side, facing the grave, shows scenes from the life of the deceased: often - as in Figure 5a - including a horseman with a small shield over his shoulder and with a lance or a gun in his hand. The man's sword is attached to the characteristic high wooden saddle. On this stele from 1882 the horseman is accompanied by three tribesmen each carrying a gun with a fixed bayonet. The other side of a man's stele shows a similar picture, but with marked differences in content. Here the representation is associated with death and burial - and possibly afterlife (Fig. 5b). The horse is riderless, and it is clearly tethered with a mallet at the head and the hind leg. The weapons of the deceased a gun, a sword and a shield - are tied to the high wooden saddle. Below this scene three women are shown, their arms resting on each others' shoulders. One carries a standard (seen to the left in the picture). They probably represent participants in the mourning ritual. In a few cases a very curious and enigmatic motif depicting a lion attacking a stag with a snake in its mouth is seen above the riderless horse (Fig. 6). But what is the meaning of the horse without a rider?

In the literary sources there are examples of an old Arab custom of tethering a horse or camel at the graveside for the use of the deceased in the afterlife. Tavernier, the French traveller, provided a late $17^{\text {th }}$ century account of burial and funeral customs in Iran (from the area of Isfahan) with some interesting details (Tavernier 1692: 722). Concerning the funerary processions, he relates that if the deceased was a person of consequence, all his horses would be saddled and bridled and some extra ones might even be borrowed for appearence's sake. On these would be placed the deceased's turban, his sabre, his bow and arrows, his lance, and in general anything that might serve to identify his standing and strength. This was, of course, 
in the case of important persons, while the ordinary people would have to make do with a more humble procession to the cemetery accompanied by the chanting and crying of mullas and passersby. Tavernier adds some other interesting details: If the deceased had been a rich man or a good soldier, his turban, his sabre, his arrows and quiver and some provisions would be buried with him. Far from being unique to Persia, to lead a horse after the hearse or bier at a funeral seems to have been if not a universal habit at least a widespread custom, as testified by the examples in Quenstedt. Quenstedt (1976: 254-256) in this case starts with a reference to the Roman historian Tacitus, who reported that the old Germanic tribes often either burned the horse and equipment of a soldier or warrior on the pyre, or buried it with him - a custom that is testified among too many peoples and in too many places and periods to be quoted here. It is in most cases a reflection of a belief in an afterlife in which the deceased will need the horse, weapons, etc., that he used to have in this life - and as such it reflected pagan rites which have - largely - been superseded by the Religions of the Book. However, some of these rites have persisted - but with a different connotation. So when an officer or warrior (be it real or "honorary" like kings and presidents) still has his headgear and weapons placed on the coffin or bier followed by a led horse, fully saddled and bridled, and taken to the grave (or put on the tombstone), this might quite conceivably be a transformation or extension of this ancient habit and idea - and a survival of very ancient beliefs.

There is, however, another possible explanation for the riderless horse as it appears on the Luristani tombstones which relates to the Shi'a Muslim religious context. The prototype of Shi'ite martyrdom is the slaughter of Imam Hussein and his followers on the plain of Kerbala in $680 \mathrm{AD}$. Hussein, the grandson of the prophet Muhammed, with his family and retinue, was travelling through southern Iraq in order to claim his hereditary right to the Caliphate from the Umayyad Caliph Yasid. But at Kerbala Hussein and his followers were caught in an ambush and besieged. On the tenth day of Muharram, called Ashura, the siege reached its bloody culmination when Yasid's army cut down Hussein after massacreing every man and boy in his retinue. The tale of this foul deed spread rapidly, and the widespread reaction was one of terror and abhorrence. The events at Kerbala became the central theme for a Shi'ite passion play called Ta'ziyeh, and as early as the tenth century great mourning processions took place in Baghdad. Muharram processions, in which the blood-stained horse of Hussein is followed by flaggelants with chains, and bloody mourners who cut their heads with swords, have since been common among Shi'ite popu- 
lations in the Near East (cf. Mortensen 1992). From an early stage it was believed that participation in the Muharram ceremonies was an aid to salvation (Chelkowski 1979: 2). Because Husseins's death was regarded as an act of redemption, it came to be believed that the commemoration of the anniversary would gain for the participants the intercession of Hussein on the Day of Judgment. Elaborate Muharram processions are known to have taken place among the nomads of Luristan. For them, the mental images evoked by a Muharram procession were so strong and potent that this kind of "illiterate religion", as it might conveniently be termed, in my opinion adds another dimension to the metaphor phrased by Umberto Eco that "...images are the literature of the layman..." when he describes the impressions created by the carved stone of a medieval church doorway on the mind of a spectator who is familiar with all the stories in the Bible but cannot read or write (Eco 1984, 41).

It is likely, therefore, that by representing the riderless, equipped horse on the tombstone in the same way that Hussein's horse is represented in the Ashura rituals in Muharram, the passing observer would be reminded of Hussein's martyrdom, and thus his attention would automatically be focused on the Day of Judgment and on pious hopes for the afterlife. As a derivation of this, the intended message could also have been that the person interred here had been of a pious observation. This seems to be quite a probable explanation and association in the $19^{\text {th }}$ century nomadic setting in Luristan, and is indirectly testified by the elegies sung by the wives of the Vali Husein Gholi Khan on the occasion of his death in ca. 1900 (cf. Mann, 145-152). If this should be the right interpretation, there is, moreover, ample proof, as shown by Calmeyer (1974) and Kippenberg (1982), that it is yet another example of an age-old pre-Islamic custom going back at least to the $1^{\text {st }}$ millennium B.C. which has survived and been turned to good use by changing the symbolic value or the content of the message while maintaining the old wrapping. Or in modern semiotic terminology: if viewed as a communicative system based on two codes, a visual and a perceptual the visual code has remained unchanged while the conceptual has changed and is still doing so.

In the interpretation of the images on Luristani tombstones, it may never be possible, with certainty, to arrive at the correct interpretation of a motif. The signs and symbols on the tombstones are comparable to a code whereby messages are converted from one form of representation to another, which means that they have to be encoded in a form that the communicants can easily interpret. In a community sharing the same religion, cultural inheritance and social background, and living at a given time in a 
particular area, this should present no problem. But if one or more of these elements are altered, the whole structural pattern and symbolic scheme of the community will be affected: as, for example, is clearly demonstrated by the forcible settlement of nomads in Luristan which has caused an abrupt discontinuation in the erection of pictorial tombstones (cf. Mortensen and Mortensen 1989, 930-951, Fig. 5). The more drastic the change, the quicker the transition of symbolic values into fossilized and sometimes incomprehensible fragments of a tradition.

The following quotation from an article by Marshall G.S. Hodgson (quoted in Hartner and Ettinghausen 1964, 161) pinpoints the problem:

In the course of history symbols live and change: once established in concrete form, they may move from context to context and be used to diverse ends. It has been suggested that there might finally also be a death of symbols - or, if not ultimately a death, at least some sort of desacralization, even if only temporary ... The death of a given symbol might be its transition into sheer un-understood tradition and then, presumably, its use simply for its esthetic form...

\section{Bibliography}

Calmeyer, Peter

1974 Zur Genese altiranischer Motive. Archaeologische Mitteilungen aus Iran, N. F., 7: 49-77.

Chelkowski, Peter J. (ed.)

1979 Ta'ziyeh, Ritual and Drama in Iran. New York: New York University Press. (New York University Studies in Near Eastern Civilization, 7)

Eco, Umberto

1984 The Name of the Rose. London: Picador.

\section{Edelberg, Lennart}

1966-67 Seasonal Dwellings of Farmers in North-Western Luristan. Folk 89: $373-401$.

Hartner, Willy, and Richard Ettinghausen

1964 The Conquering Lion, The Life Cycle of a Symbol. Oriens 17: 161-171.

Kippenberg, H. G.

1982 Zu einem normativen Symbol Vorderasiens: das gesattelte Pferd. Visible Religion 1: 76-97.

Macdougall, Elisabeth B., and Richard Ettinghausen

1976 Introduction. In: Elisabeth B. Macdougall and Richard Ettinghausen (eds), The Islamic Garden; pp. 3-10. Washington: Dumbarton Oaks Trustees for Harward. (Dumbarton Oaks Colloquium on the History of Landscape architecture, 4) 
Mann, 0.

1910 Die Mundarten der Lur-Stämme im Südwestlichen Persien. Berlin. Georg Reimer.

Mortensen, I. D.

1983 Women after Death: Aspects of a Study on Iranian Nomadic Cemeteries. In: Bo Utas (ed.), Women in Islamic Societies; pp. 26-47. London: Curzon Press).

1991 From Ritual Action to Symbolic Communication. In: Paul Garwood et al. (eds), Sacred and Profane. Proceedings of a Conference on Archaeology, Ritual and Religion, Oxford, 1989; pp. 80-87. Oxford: Oxford University Committee for Archaeology. (Oxford University Committee for Archaeology, Monograph, 32)

1992 On the Development and Role of the Ta'ziyeh Play in Popular Islam. In: Bo Utas and Knut S. Vikør (eds), The Middle East Viewed from the North; pp. 104-113. Bergen: Nordic Society for Middle Eastern Studies.

Mortensen, I. D., and P. Mortensen

1989 On the Origin of Nomadism in Northern Luristan. In: L. de Meyer and E. Haerinck (eds), Archaeologia Iranica et Orientalis. Miscellanea in Honorem Louis vanden Berghe; vol. 2; pp. 929-951. Gent: Peeters Presse.

Quenstedt, 0 .

1976 Wort und Brauch im deutschen Heer "Transfeldt". Hamburg: H. G. Schulz. [7. ed.]

Rainer, Roland

1977 Anonymes Bauen im Iran. Stadtplanungsab. D.N.I.S.C. Graz: Akademische Druck- und Verlagsanstalt.

\section{Schimmel, Annemarie}

1976 The Celestial Garden in Islam. In: Elisabeth B. Macdougall and Richard Ettinghausen (eds), The Islamic Garden; pp. 11-40. Washington: Dumbarton Oaks Trustees for Harward. (Dumbarton Oaks Colloquium on the History of Landscape Architecture, 4)

Tavernier, Jean Baptiste

1692 Les Six Voyages de Jean Baptiste Tavernier ... en Turquie, en Perse, et aux Indes ... Paris: G. Clouzier.

Thacker, Christopher

1979 The History of Gardens. London: Croom Helm.

Wilber, Donald N.

1962 Persian Gardens and Garden Pavilions. Tokyo, C. E. Tuttle. 